\title{
高温における低炭素鋼の切欠きクリープ破断に関する一考察*
}

(クリープ中に括ける切欠き材拈よび平滑材の応力分布の変化)

\author{
大南 正 瑛** 阿波屋義照*** \\ 元 家 勝 彦****高 田 晄 男*****
}

\section{A Study on Creep Rupture of Notched Sheet Specimens of Low Carbon Steel at Elevated Temperature}

by

\author{
Masateru OHNAMI \\ (Faculty of Science and Engineering, Ritsumeikan University, Kyoto) \\ Yoshiteru Awaya \\ (Maizuru Technical College, Maizuru) \\ Katsuhiko MotoIE \\ (Hiroshima Denki University, Hiroshima) \\ and Mitsuo TAKADA \\ (Maizuru Technical College, Maizuru)
}

From the tests of tensile creep rupture in notched plate specimens of 0.098 per cent carbon steel at $500^{\circ} \mathrm{C}$, the following conclusion can be derived.

(1) There was considerable change in stress distribution on the cross section of the notched bottom during the early stage of the creep, but after a time no remarkable redistribution was observed.

(2) The notch-strengthening effect of creep rupture strength of the material tested was examined on the basis of the nominal stress. On the basis of the equivalent steady stress, whose increase of the true stresses with progress of creep was taken into account, the difference in rupture life between the notched specimens and the smooth specimens was found smaller than that on the basis of the nominal stress. However, the behavior of notch-strengthening was still fixed.

(3) In order to determine such a notch-strengthening effect, the following stress condition was estimated. This is the case where the level of hydrostatic component of stress at near part of the notch bottom of the notched specimen is lower than that at the middle part on the cross section, and the former level is lower than that at near part of the bottom of the smooth specimen.

(4) The initial rectangular anisotropy of the material tested was examined experimentally, but neither the level of the equivalent steady stress nor multiaxiality of the stress was affected by the present anisotropy of the material.

(Received Nov. 2, 1970)

\section{1 緒言}

切欠きクリープ破断関する研究は, 構造物要素の 高温クリープ破壞飞対する対処々いう実際的な必要か ら，また多軸応力下のクリープ破壊の問題としてきわ めて重要な課題であり, その系統的な研究が望まれて

\footnotetext{
* 原稿受理 昭和45年11月 2 日

** 正会員 立命館大学理工学部 京都市北区等持院北町

*** 正 会 員 舞鹤工業高等専門学校 舞鶴市字白屋

***** 正会 員 広島電機大学 広島県安芸郡賉野川町

***** 舞鶴工業高等専門学校 舞鶴市字白屋
}

いる．歴史的には，前者の観点から切欠き強化と切 欠き弱化現象を個別材料, 個別試験条件について実験 的に調ベることに多くの努力が積重ねられてきたし， 後者については多軸応力下のクリープ破壊強度を多軸 クリープ変形の理論にてらして単軸クリープ破壊強度 から推定する研究の一環として, 高温クリープ破壊を 支配する主因子を調べることに多くの努力が払われて きた、にもかかわらず，両者についていまだ統一的な 法則性を見い出す段階に至っていないのが現状である 
と思われる。しかしながら, 後者については最近, 高温 クリープおよびその破壊に扤よぼすひずみ履歴や静水 圧応力の影響に関する研究が系統的にすすめられ, た とえば内圧円筒の高温クリープ破壊を支配する諸因子 をある程度系統的に整理できる段階にきていると思わ れる.したがって, 切欠きクリープ破断についても切 欠き強化拉よび切欠き弱化のそれぞれの因子を系統的 に整理していくことは重要なことがらであると考える。

本研究は, 高温クリープ破壊に执よぼすひずみ履歴 扣よび静水圧応力の影響に関する力学研究を通じて, 切欠きクリープ破断の機構を明らかにする研究の一環 として行なったものである.とりわけ，本考察では切 欠き強化の力学因子を明らかにする第一歩として, ク リープ中に括ける切欠き底横断面のひずみ分布の実測 とそれに基ついて解析された応力分布から推論される 静水圧応力のクリープ破壊への寄与について述べるこ

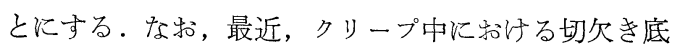
のひずみ解析が有限要素法の適用によってすすめられ て抢り，その実験的検証と併行してこの分野の研究に 寄与するところが大きいものと期待される。

\section{$2 \cdot 1$ 試験片}

\section{2 実験材料および実験方法}

文献によれば平滑試験片の高温クリープ破断伸びの 大きい材料では切欠き強化（切欠き破断強度比 NRSR, または切欠き破断時間比 RTR が1より大）になるこ とが多いといわれている。したがって，本実験では， 後述するよ5にクリープ中での切欠き底のひずみ測定 精度を保証することも考慮して, 破断伸びのきわめて 大きい極軟鋼（化学成分は Table I 飞示す）の SPHC 王延鋼板を供試材とし, 試験片は圧延方向およびそれ と直角方向より採取した．試験片形状はFig. 1 に示す 板状試験片であり，切欠き形状は Neuber 切欠さとし てその切欠き半径 $1 \mathrm{~mm}$ の $60^{\circ} \mathrm{V}$ 形に隼じたもの（図 の点線で示す双曲線切欠き) であり, 応力集中係数は 3.56 である。なお，図の実線に示す直線 $60^{\circ}$ 切欠き形 状をもつ場合の応力集中係数は有限要素法による弾性 計算では3.72であった。（付録参照）試験片はすべて 最初, 圧延方向に沿って採取し, その後初期異方性を 検証するための平滑小試験片をFig. 1 の平滑材の㨡及 部からFig. 2 の寸法形状でもって採取した。このよう な小試験片のクリープ破断試験を行ならため, 同じく Fig. 2 に示すようなアタッチメントをとくに用意した。

Table I. Chemical composition of SPHC rolled steel plate.

\begin{tabular}{c|c|c|c|c|c|c}
\hline $\mathrm{C}$ & $\mathrm{S} 1$ & $\mathrm{Mn}$ & $\mathrm{P}$ & $\mathrm{S}$ & $\mathrm{Cr}$ & $\mathrm{Cu}$ \\
\hline 0.098 & 0.010 & 0440 & 0.013 & 0027 & 0020 & 0040 \\
\hline
\end{tabular}
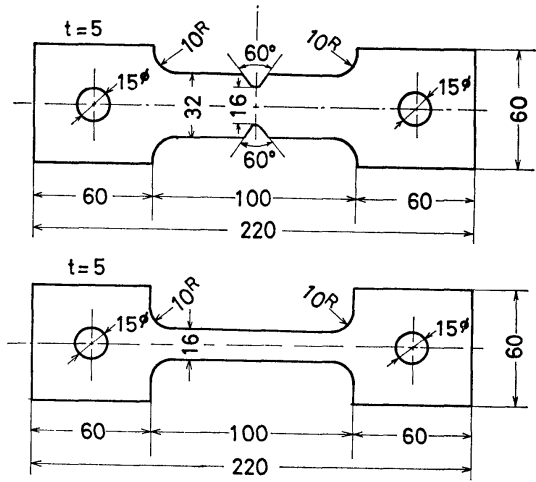

$60^{\circ} \mathrm{V}$ Notch (Neuber notch)

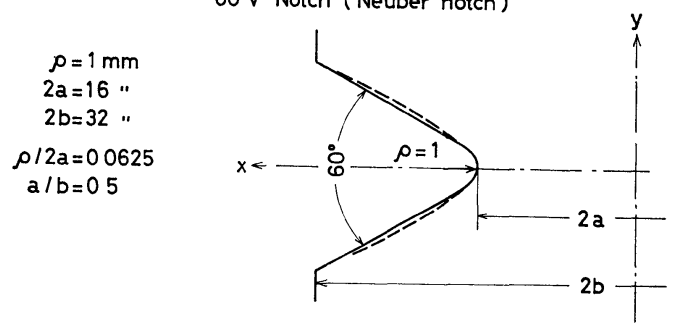

F1g. 1. Sharp and size of notched and smooth specimens.

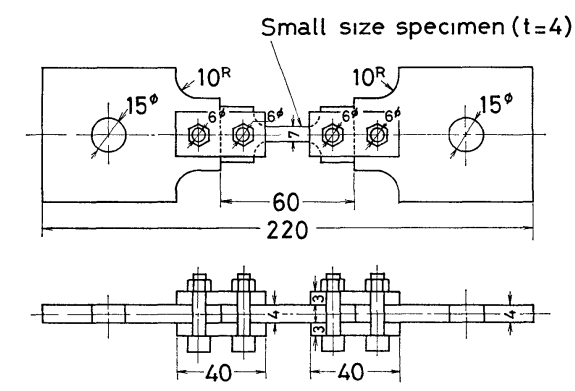

Fig 2. Small size smooth specimen and the attachments.

また, 試験片の切欠きはフライス加工によって行ない, 試験片はすべて加工後そのままクリープ破断実験に供 した。

\section{$2 \cdot 2$ ひずみの測定方法}

クリープひずみの測定は試験片の㨡み部に設けた伸 び計(ダイヤル・ゲージ)によるものと，他方切欠き底 全体に $2 \mathrm{~mm}$ 間隔で正方形格子ケガキ線を入れてケカ キ線の変位をフィルムに納めることによって計測する 方法の二種類のものを採用した。な拉，ケガキ線をひ くについては酸化により線が不鮮明になることをさけ るため, あらかじめ耐熱塗料（フシカンマー 塗布した。ケガキ線の変位測定は，フィルムを投影器 （50倍に拡大）にかけて行ない，またせん断ひずみは二 つの垂直ひずみに比べてその精度のうえで無視するこ

*1 シルバー色, 比重 1.6, 耐熱性は $500^{\circ} \mathrm{C}$ て。 
とにした。もっとも切欠き底横断面上のひずみ測定を 主眼においているのでせん断ひずみ成分は無視してさ しつか光ない。な特，垂直ひずみの測定できる最小読 久は $0.05 \%$ でる。

\section{$2 \cdot 3$ クリープ応力の解析法}

応力解析には通常用いられる基本的仮定のほかに， 本解析では以下のことがらを仮定した。すなわち，(1) Mises の降伏条件と乞の流机の式, (2)切欠き横断面に おいてせん断ひずみ速度 $\dot{\gamma}_{x y}$ は垂直ひずみ速度 $\dot{\varepsilon}_{x}, \dot{\varepsilon}_{y}$ に比べて無視する。ここで $y$ 軸は压延方向に一致する 試験片軸とし，それに直角方向を $x$ 軸とする。(3)変形 異方性は考慮しない，ただし，初期異方性は考慮する。 (4)クリープ破断を含を全クリープ段階のクリープ速度 としては第 2 期クリープ（最小クリープ速度）を対象 とする $\dot{\varepsilon}=k \sigma^{n}$ の形式の関係式で近似する。ここで $k$, $n$ は温度一定の々き定数である。したがって任意時刻 飞持㤝る切欠き底横断面の局所的なクリープ応力成分 $\sigma_{y}$ 特よび $\sigma_{x}$ は次式で与兄られる。

$$
\sigma_{y}=\frac{2}{3} \frac{\bar{\sigma}}{\dot{\varepsilon}}\left(\dot{\varepsilon}_{x}+2 \dot{\varepsilon}_{y}\right), \sigma_{x}=\frac{2}{3} \frac{\bar{\sigma}}{\overline{\dot{\varepsilon}}}\left(2 \dot{\varepsilon}_{x}+\dot{\varepsilon}_{y}\right)
$$

ここです特よびを屿とれぞれ相当応力特よび相当ひず み速度である。

\section{$2 \cdot 4$ 初期異方性の解析法}

ここで用いる初期異方性の解析は, Mises-Mises の 条件式拉よび Hill の式の拡張として, 次式の降伏関 数 $f^{8}$ り導かれるクリープ式にもとづいて行なうこと にする。すなわち，

$$
\begin{aligned}
f= & \bar{\sigma}^{2}=\alpha_{x y}\left(\sigma_{x}-\sigma_{y}\right)^{2}+\alpha_{y z}\left(\sigma_{y}-\sigma_{z}\right)^{2} \\
& +\alpha_{z x}\left(\sigma_{z}-\sigma_{x}\right)^{2}
\end{aligned}
$$

を用いると, 流れの式 $\dot{\varepsilon}_{\imath \jmath}=\lambda\left(\partial f / \partial \sigma_{\imath \jmath}\right), \lambda=\bar{\varepsilon} / \bar{\sigma}$ より 次式をらる。

$$
\begin{aligned}
& \dot{\varepsilon}_{y}=\frac{\bar{\varepsilon}}{\bar{\sigma}}\left(\alpha_{y} \sigma_{y}-\alpha_{x y} \sigma_{x}\right), \\
& \dot{\varepsilon}_{x}=\frac{\bar{\varepsilon}}{\bar{\sigma}}\left(\alpha_{x} \sigma_{x}-\alpha_{x y} \sigma_{y}\right)
\end{aligned}
$$

ただし， $\alpha_{x}=\alpha_{x y}+\alpha_{z x}, \alpha_{y}=\alpha_{y z}+\alpha_{x y}, \alpha_{z}=\alpha_{z x}+\alpha_{y z}$ であり，降伏条件として $f=K^{2}$ と拈き，かつ $\sigma_{x}=Y_{x}$, $\sigma_{y}=Y_{y}, \quad \sigma_{z}=Y_{z}$ と物く之 $\alpha_{x}=\left(K / Y_{x}\right)^{2}, \quad \alpha_{y}=(K)$ $\left.Y_{y}\right)^{2}, \alpha_{z}=\left(K / Y_{z}\right)^{2}$ となる.ここで $Y_{x}, Y_{y}, Y_{z}, K$ 法先杂帒れ降伏応力である。いま, 切欠き底横断面上 （圧延之直角の方向）の応力解析を考光ているので, $\alpha_{y}=\left(Y_{z} / Y_{x}\right)^{2}=1 ， \alpha_{z}=\left(Y_{z} / Y_{z}\right)^{2}=1$ (ただし $\left.Y_{z}=Y_{x}\right)$ を仮定すれば, $\alpha_{x y}=\alpha_{x} / 2$ の関係が光られるので結局 (3)式は次式で与克られる。

$$
\begin{aligned}
& \dot{\varepsilon}_{y}=\frac{\bar{\varepsilon}}{\bar{\sigma}}\left(\sigma_{y}-\frac{\alpha_{x}}{2} \sigma_{x}\right), \\
& \dot{\varepsilon}_{x}=\frac{\bar{\varepsilon}}{\bar{\sigma}}\left(\alpha_{x} \sigma_{x}-\frac{\alpha_{x}}{2} \sigma_{y}\right)
\end{aligned}
$$

ここで $\alpha_{x}=\left(Y_{z} / Y_{y}\right)^{2}=\left(Y_{x} / Y_{y}\right)^{2}$ で与えられるので,
それは任意の同一クリープ速度に対する（直角方向よ り抽出される平滑試験片に対するクリープ応力 $)^{2} /$ (圧 延方向より抽出される平滑試験片汇対するクリープ応 力 $)^{2}$ で与兄られる. (4)式を $\sigma_{y}, \sigma_{x}$ について解くと

$$
\begin{aligned}
& \sigma_{y}=\frac{2}{4-\alpha_{x}} \frac{\bar{\sigma}}{\bar{\varepsilon}}\left(\dot{\varepsilon}_{x}+2 \varepsilon_{y}\right), \\
& \sigma_{x}=\frac{2}{\alpha_{x}\left(4-\alpha_{x}\right)} \frac{\bar{\sigma}}{\bar{\varepsilon}}\left(2 \dot{\varepsilon}_{x}+\dot{\varepsilon}_{y}\right)
\end{aligned}
$$

とあり，ここで $\alpha_{x}=1$ とおくと(5)式は(1)式（初期等 万性）と一致する。

\section{3 実験結果およびその考察}

\section{$3 \cdot 1$ 平滑試験片に対する結果}

Fig. 3 打よび 4 はそれぞれ压延方向叔よびそれ之直 角方向に採取した平滑試験片の温度 $500^{\circ} \mathrm{C}$ に括ける 各 クリープ曲線示し, 明らか飞直角方向のものが圧延 方向のものに比べて破断伸びが大きくかつ破断寿命が 短かくなる。したがって，供試材は高温クリープ破断 性質に対して初期異方性（直交異方性）をるつ。な括, Fig. 3 のクリープ曲線の点線は平滑試験片長手方向中 央部に設けたケガキ線による局所伸びである．Fig. 5 は公称応力と最小クリープ速度関係を坧延方向特上び 直角方向より採取した試験片に対して示したものであ り，前述したように異方性のパラメータ $\alpha_{x}$ は Fig. 5

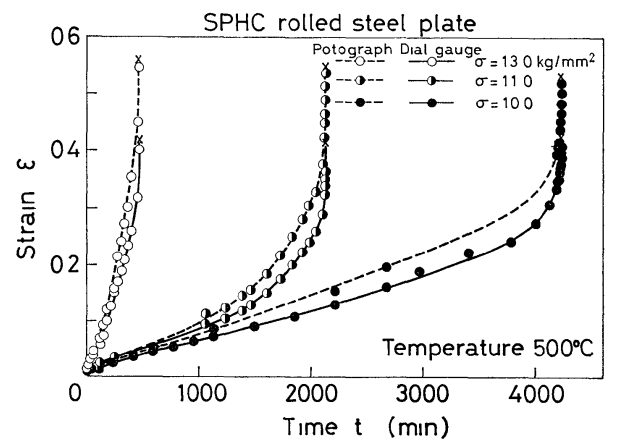

Fig. 3. Creep curves of the smooth specimen of which axis direction is the same as the rolled one.

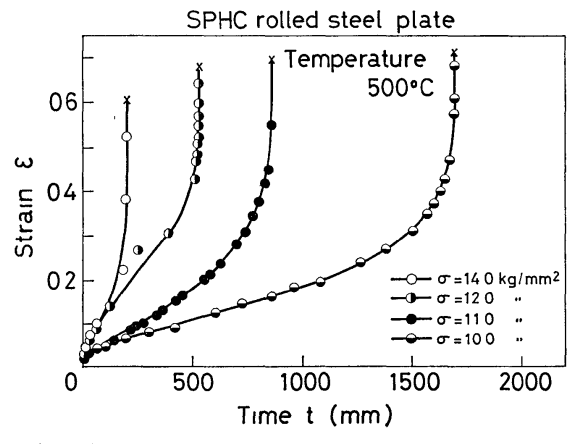

Fig. 4. Creep curves of the small size smooth specimen of which axis direction is rectangular to the rolled one. 


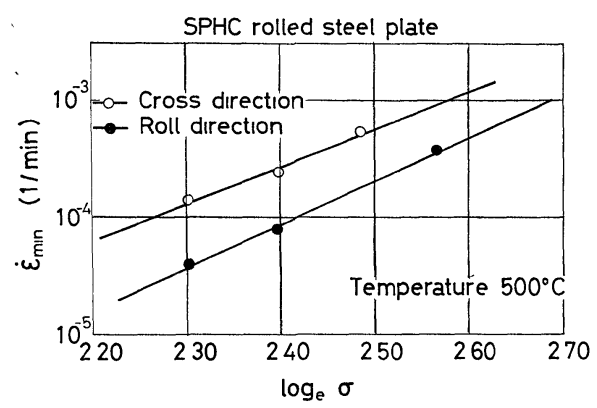

Fig. 5. Experimental relation of minimum creep rate to applied nominal stress of two types of the unnotched specimens.

\section{より求められる（この場合 $\alpha_{x}<1$ ).}

\section{$3 \cdot 2$ 切欠き試験片に対する結果}

Fig. 6 は圧延方向からともに採取した平滑試験片之 切欠き試験片に対するクリープ破断時間曲線を公称引 張応力 $\sigma_{y 0}$ の基準でもって比較したものであり明らか に切欠き強化を示し，RTR は約2.3となる。ところで この切欠き強化を支配する因子を調べることを目的と して以下のように切欠き底横断面のひずみ計測とそれ に基づく応力解析を行なった。な拉，Fig. 6 の右縱軸 に示す定常相当応力 $\bar{\sigma}_{e}$ を基準とする比較については 後で詳述する。

Fig. 7 (a) から (c) は公称引張応力 $14.0 \mathrm{~kg} / \mathrm{mm}^{2}$ の もとで切久き底横断面のひずみ分布を各クリープ時間 そついて実測した結果を示し，Table II は切欠き底 横断面比蚂る軸方向（y方向）ひずみを中心部抒よ び切欠き底について示したものである。また，Fig. 8 は, 同じく $14.0 \mathrm{~kg} / \mathrm{mm}^{2}$ のもとでの初期等方性の切

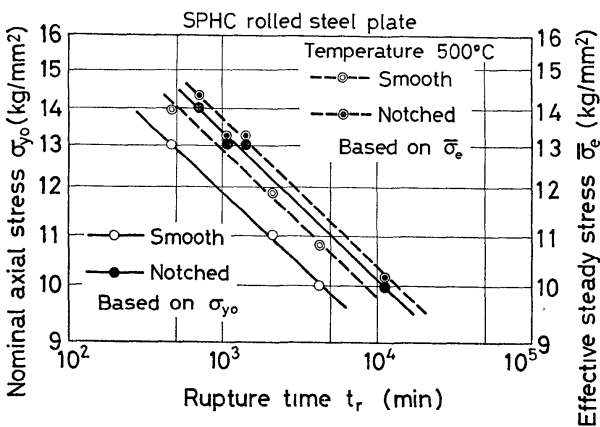

Fig. 6. Comparison between the rupture time of the notched specimen and that of the unnotched specimen.

Table II. Variation of measured strain ratio of $\varepsilon_{y}$ at $x / a=1$ to that at $x / a=0$ with elapsed time of creep loading.

\begin{tabular}{c|c|c|c}
\hline $\begin{array}{c}\text { Elapsed time } \\
(\mathrm{min})\end{array}$ & $\begin{array}{c}\hat{x} y(\%) \text { at } \\
x / a=0\end{array}$ & $\begin{array}{c}\varepsilon_{y}(\%) \text { at } \\
x / a=1\end{array}$ & Strain ratio \\
\hline 30 & 1.5 & 4 & 27 \\
570 & 18 & 50 & 2.8 \\
701 & 48 & 102 & 2.1 \\
\hline
\end{tabular}

欠き材の切欠き底横断面の応力分布の解析例を示す. な和, 応力分布の解析結果の妥当性を検証する一方法 として, 軸方向応力分布から塑性的体積不変則を用い て逆算した負荷重は実荷重と $5 \%$ 程度の誤差内で一致 した。

Fig. 8 から少なくとも次の二点のことがらを指摘す ることができる。一つは, 切欠き底横断面の応力分 布はクリープの比較的初期に抒いて急激汇变化しすで に応力集中が緩和されて以後の分布は大きく变わらな
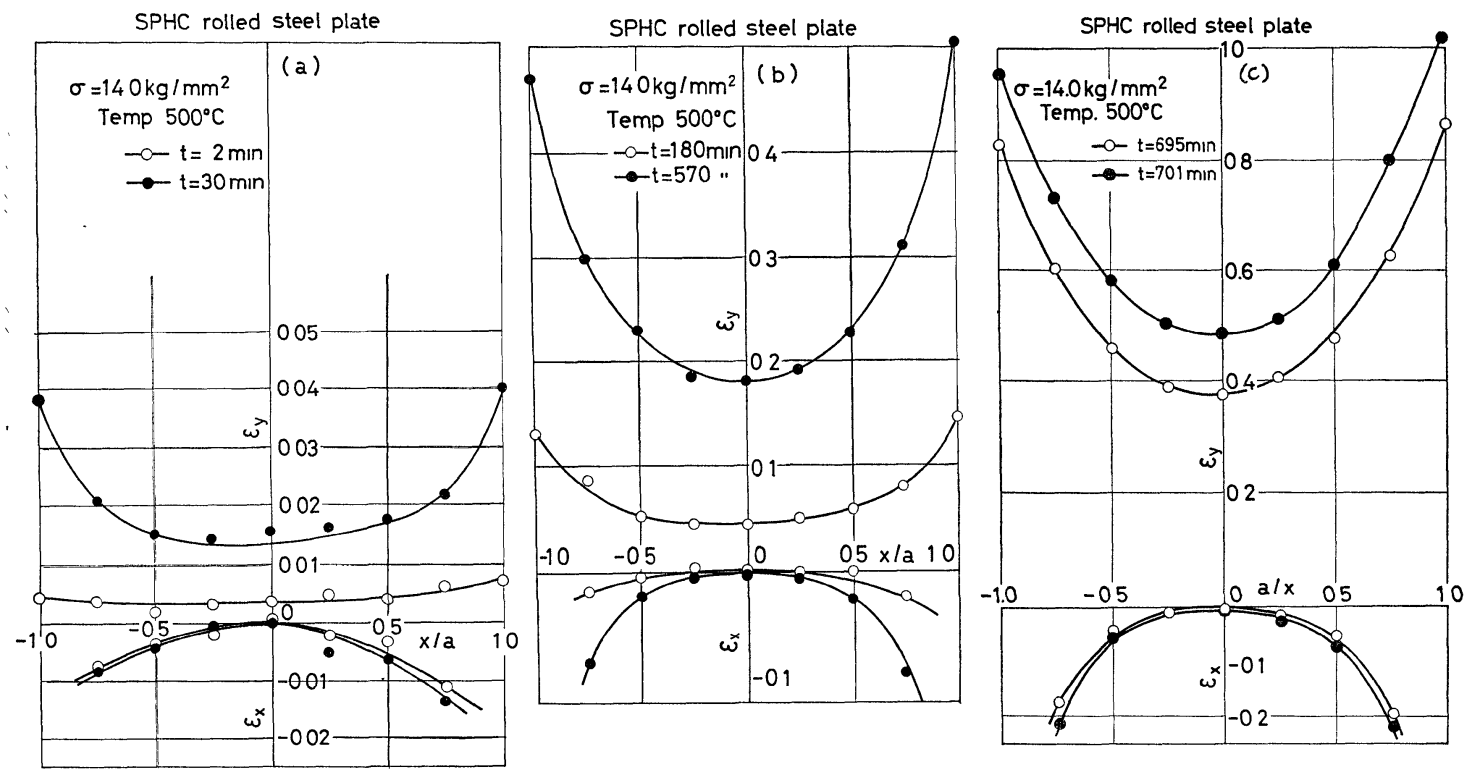

Fig. 7. (a), (b), (c) Strain distributions on the cross section of the notch bottom during creep loading. 
SPHC rolled steel plate

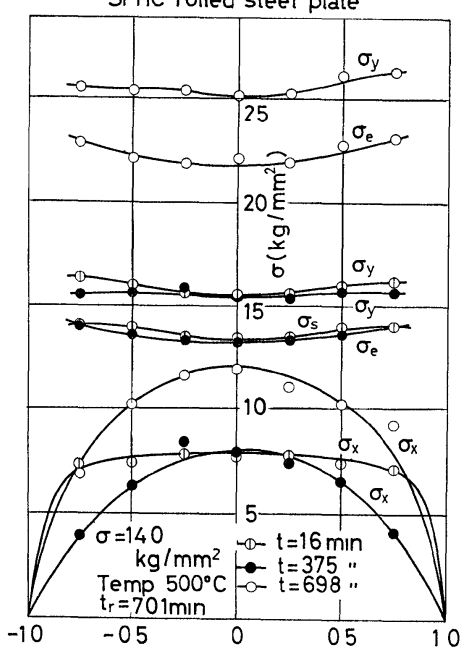

Fig. 8. Stress distributions on the cross section of the notch bottom during creep loading. いことである。 ただし, 破断寸前においては各応力成 分の值は著しく大きくなる。第二に, 切欠き底横断面 の中心部に拈いて $\sigma_{x}$ は最大になり，したがって応力 の正の多軸性（2軸性）が大きくなることである.以 上の実験結果をもとにして, 以下に本材料の切欠き強 化の原因を考察することにする.

\section{$3 \cdot 3$ クリープにともなう応力増加の影響}

切欠き強化現象を定量的に説明するための前提とし て，平滑材和よび切欠き材のクリープ破断に至るまで のクリープにともなら真応力の増加の影響についてま ず考察を行なっておく必要がある。

Fig. 9 注，公称応力 $13.0 \mathrm{~kg} / \mathrm{mm}^{2}$ に和计る切欠き 材および平滑材のクリープにともなら真応力の多軸性

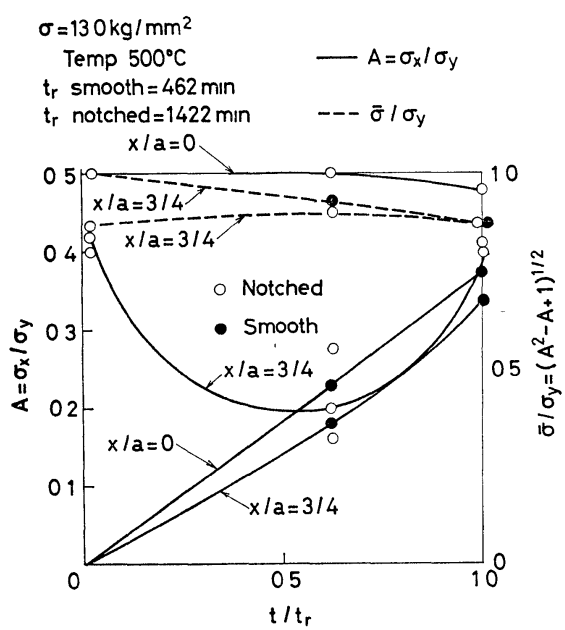

Fig. 9. Variation of multiaxiality of the stresses $A$ and the equivalent stress $\bar{\sigma}$ with loading time ratio $t / t_{r}$ for the notched and unnotched specimens.
(ここでは応力比 $A=\sigma_{x} / \sigma_{y}$ で示す）および相当真応 力 $\bar{\sigma}$ (軸方向の真応力 $\sigma_{y}$ で無次元化) の変化を示し たものである、図において実線は $A$ を, 点線は $\bar{\sigma}$ (右 側縦軸に表示）を示し, 横軸は負荷時間比 $t / t_{r}\left(t_{r}\right.$ は 切欠き材拉よび平滑材のそれぞれの破断時間) で示し た.ただし, 図で $x / a=0$ の $\bar{\sigma} / \sigma_{y}$ の值は $x / a=3 / 4$ に拈けるそれと大差がないので省略した。 また，平滑 材に执いて $t / t_{r}=0$ なるとさ $A=0$ と打いたのは負荷 の瞬間に拈いて $\sigma_{x}=0$ を考えたことにほかならない。 なお，平滑材に対する $A$ の值は，同試験片に切欠き試 験片の場合と同様の格子ケガキ線を入れることによっ て求めたものである. 図の点線からわかるように, 平 滑材の相当真応力は, 試験片横断面全体について（切 欠き材のときは切欠き底横断面）ならびに全クリープ 過程を通じて，切欠き材のそれよりいくぶん大きくな り，とりわけクリープの初期において大きくなる。こ のことは他の公称応力レベルでのクリープ実験結果に ついても同じことがいえる。

では, 相当真応力の比較基隼で雨試験材のクリープ 破断実験結果はよい一致をみるであろらか。結果的に はクリープ中の相当応力の増加を考慮に入れた相当定 常応力 $\bar{\sigma}_{e}$ (相当応力漸増下のクリープ破断時間 と同 一の時間でクリープ破断するような一定の換算相当応 力）でもって比較しても両者は必らずしもよい一致を みない.すなわち, Fig. 9 の $\bar{\sigma} / \sigma_{y}$ に基づく $\bar{\sigma}_{e} / \sigma_{y}$ の計 算值は，実験を行なった範囲に打いて切欠き材の場合 0.89-0.90であり, 平滑材の場合は 0.94-0.95であ る.ゆえに, 両試験片に技ける $\sigma_{y}$ は破断寸前で急増 する以外は断面収縮にともなって $\sigma_{y} / \sigma_{y 0}=1+\varepsilon_{y} \approx 1.15$ 程度に単調に増加するのと見積ると（ $\varepsilon_{y}$ は負荷時間比 $t / t_{r} \approx 0.5$ で 0.15 程度で見積る)，切欠き材および平滑 材のクリープ破断曲線は $\bar{\sigma}_{e}$ の比較基準による場合は Fig. 6 の点線のよ5になる. Fig. 6 の点線表示に括い て， $\bar{\sigma}_{e}$ による比較基準 は初期引張応力 $\sigma_{y 0}$ によるも のに比べて明らかに両実験結果の差を縮めることに寄 与するが (RTR で約 1.7 となる)， $\bar{\sigma}_{e}$ を用いてもなお 切欠き材の破断寿命が平滑材のそれに比べて長くある ことには変わりがない、したがって，切欠き材のクリ 一プ破断寿命を平滑材のそれより Mises の相当応力 基隼で推定する際, クリープにともな5真応力の増加 を考慮するだけでは不充分であり，それ以外に切欠き 材の破断寿命が長くなる因子あるいは平滑材のそれが 短かくなる因子を付加的に考慮しなければならない。

\section{$3 \cdot 4$ 応力多軸性, とりわけ静水圧応力成分の影響}

上述の付加的因子としてまず考えられることは応力 の多軸性, とりわけ正の静水圧応力成分の影響である. 一般に金属材料の破断に対して応力の多軸性が顕著な 影響をもつことが知られて扣り，金属材料の高温クリ 
ープ 破壊に対してもこのことが内圧 円筒管の破壊な ぞを通じて指摘されてきた。しかし，静水圧力下の高 温クリープおよびその破壞の実験をつうじて, 負の静 水圧応力が定常クリープ速度を著しく減少させから破 断寿命を著しく増大させる効果をるつことについて定 量的な評価が行なわれたのはごく最近のことである。 ここでは, 切欠きクリープ破断寿命に拉よ淁す正の静 水圧応力の影響について考察することにする。

さきに述べたFig. 9 の実線に示吉応力比 $A$ にいて 調べると, 平滑材の $A$ は $t / t_{r}$ 汶対して注ぼ直線的に 增大し, ᄂか子横断面中心部 $(x / a=0)$ と切欠き底近

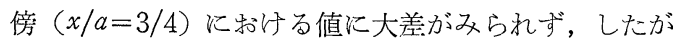
って $x / a=1$ のごく近傍を除いて横断面に拈ける $A$ の 值の分布は全クリープ過程を通じてほぼ一様と考光ら れる.これに対して,切欠き材の場合には，切欠き底横 断面中心部の $A$ の值がクリープ破断至る間 $A \approx 0.5$ と平滑材より大きな值をとりしかもとれがほとんど変 化しないのに比べて，切欠き底近傍 $(x / a=3 / 4)$ では $A$ 值が中心部のそ机より小さくかつ時間的に大きく 変動し, 第 2 期クリープ段階では平滑材の $A$ の值もし くはそれ以下の值まで低下する。な扮，切欠き材の $x / a=3 / 4$ 飞和将る $A$ の值は，切欠き材の左右切欠き 部の応力分布が実験結果のバラッキが多少左右非対称 となることもあって多少のバラッキがあるが，Fig. 9 の実験の傾向は他の応力レベルのクリープ実験結果に 执いてる確認することができる。したがってこの種の 材料の切欠き強化の一因として，切欠き底近傍に打け る正の静水圧応力成分がクリープ中，とりわ知第 2 期 クリープ段階に求いて平滑材の挙動と反対飞激減する 効果を推測することができよう、な执，高温クリープ 破断寿命に拈よ汴す正の静水圧応力成分の影響につい ては，同一相当応力についてその成分の值が大きくな るほど寿命は短かくなり反対にその值が小さくなる汪 ど長くなる傾向炕ある。しかしながら，切欠き強化炕 お上活す静水圧応力成分の寄与についてはさらにクラ ックの伝ぱに打よ汸す同成分の影響も含めて，さらに 詳細な検討が必要であり,今後継続して研究をすすめ る予定であることを付言しておく。

\section{$3 \cdot 5$ 初期異方性の影響}

初期異方性を考慮した場合の $x$ 打よび $y$ 方向の各ク リープ応力成分は前述の(5)式で与兄られるが，これら の式比护る直交異方性のパラメータ $\alpha_{x}$ はFig. 5 亿 示した最小クリープ速度一応力曲線より求めることが できる。初期異方性の影響については，たとえばFig. 10に示すよ弓に応力の多軸性に対してほとんど影響を 与えないことがわかる。

\section{4 結言}

極軟鋼（SPHC 圧延鋼板）の切欠き板状試験片の温

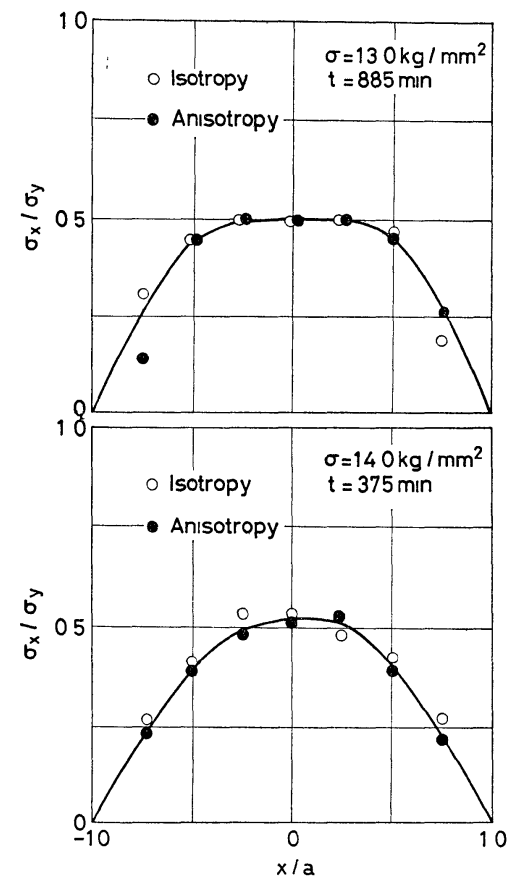

Fig. 10. Effect of initial anisotropy of the material on the distribution of multiaxiality of the stresses along the cross section of the notch bottom.

度 $500^{\circ} \mathrm{C}$ に和将るクリープ破断実験結果から以下のこ とがらが結論できる。

（1）切欠き底横断面の応力分布はクリープの比較的

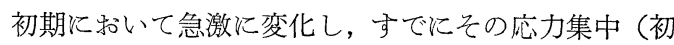
期の応力集中係数は3.56）が緩和されて以後の分布は クリープ中大きく変わらず，ひずみの集中率も汪とん ど変化しない。

（2）本材料のように高温クリープに対して大きな延 性を示寸材料では, 公称応力基準によるクリープ破断 寿命について明らかに切欠き強化（RTR で約2.3）を 示すが、クリープにともなら応力增加を切欠き材拈よ び平滑材ともに考慮した相当定常応力基準による比較 に括いても，両者の差が公称応力基準のものよりいく ぶん小さくなるものの，切欠き材の寿命が平滑材のそ れより長くなることには変わりがない，

（3）この差を説明する一因子として，切欠き底近傍 飞和活る正の静水圧応力成分の值が切欠き底横断面中 央部に括けるとれより低くなり，さらに平滑材のくび 礼底近傍に沶㺭る正の静水圧応力成分の值より低くな る場合を推定できるが，この点についてはさらに詳細 な検証が必要である。

（4）本供試材は圧延方向とそれに直角方向によって クリープ破断時間が異なり（直角方向に沶いてクリー プ破断寿命が短かくなる）初期直交性をるつが，相当 定常応力拈よび応力の多軸性に対して汪とんど影響を 
与党ない。

本研究を行ならにあたり試験片の提与をえた豊田中 央研究所の青山咸恒および並川宏彦両氏に対して感謝 するとともに，本実験に卒業研究の一環として協力さ れた当時, 立命館大学理学部学生の大島康弘拉よび中 野金一郎両君に対して識意を表するものである。

\section{付 録}

直線 $60^{\circ} \mathrm{V}$ 切欠き（曲線半径 $\rho=1 \mathrm{~mm}$ ) の応力集中

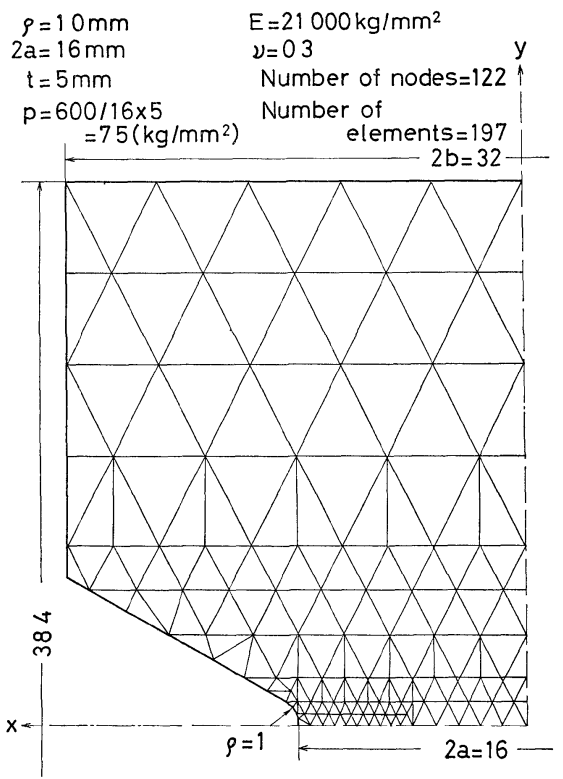

Fig. 11. Element division for fintte element analysis of notched specimen.

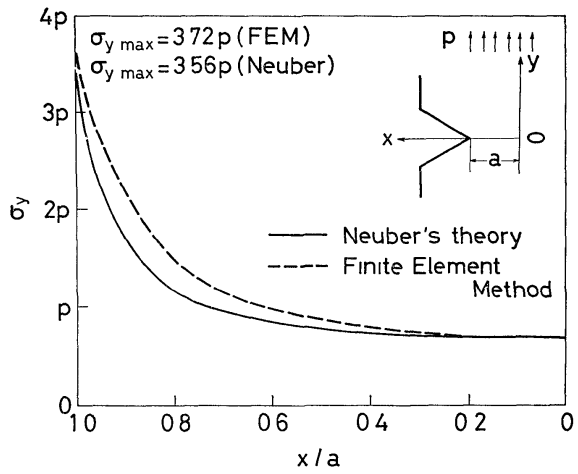

Fig. 12. Comparison between the analytical distribution of axial stress on the cross section of the notch bottom based on Neuber's theory and that based on finite element method.
係数の算定は Fig. 11 に示す三角要素による有限要素 法による弾性計算によった。なお，要素数は，197， 節点数は 122 , 荷重は $600 \mathrm{~kg}$ で平均応力 $p=7.50 \mathrm{~kg} /$ $\mathrm{mm}^{2}$ である. Fig. 12 の点線は, 有限要素法による切 欠き底横断面上に和ける軸応力 $\sigma_{y}$ の分布を示し, そ の切欠き底に执沪る最大応力は $\sigma_{y \max }=3.72 p$ となる。 他方, 図の実線は, 双曲線 $60^{\circ} \mathrm{V}$ 形切欠きの $\sigma_{y}$ の 分布を Neuber の弾性式によって求めたものであり, 図からわかるように Neuber の $\sigma_{y \max }=3.56 p$ は有限 要素法によるものよりいくぶん低くなり，また横断面 上の $\sigma_{y}$ の分布值も有限要素法によるものより低くな る.

（昭和45年 8 月26日 第10回高温強度シンポジウムにて講窝）

\section{参考文 献}

1）たとえば，総括的なものとして，ASTM, STP. No. 128 (1952); ASTM, STP. No. 260 (1959); 宮川松男, “ク リープ変形理諭と設計,"（1963）日刊工業新聞.

2）たと衤ば，総括的なものとして，平 修二，大谷隆一， “金属材料の高温強度 (平 修二編),” p 163 (1968) 養 賢堂.

3) 大南正瑛, 材料, 16, 161 (1967) : 大南正瑛, 元家勝彦, 吉田信夫, 材料, 18, 226 (1969).

4) 大南正瑛, 元家勝彦, Proc. 12 th Jap. Cong. Mat. Res., 78 (1969) ; 大南正瑛, Proc. 13 th Jap. Cong. Mat. Res., 120 (1970) ; 元家勝彦, 山蔭哲郎, 大南正瑛, 第14 回材料研究連合講演会前刷, p. 147 (1970-10) 材料に投 傐中; 大南正暎, 元家勝彦, 山蔭哲郎, 材料, 20 , 395 (1971).

5) 大南正瑛, 元家勝彦, 材料, 20, 236 (1971).

6) 大谷隆一, 材料, 19, 160 (1970); 平 修二, 大谷隆一, IUTAM, Symposium (1968), “Thermoinelasticity” (ed. B. A. Boley), p. 297 (1970) Springer-Verlag

7) 平 修二, 大谷隆一, 伊藤 隆, 第14回材料研究連合講 演会前刷, p 91 (1970-9).

8) Hu, L.W., J App. Mech., 21, 444 (1954).

9) 田中吉之助, 中島 稔, 材料, 12,142 (1963).

10）大南正瑛, 阿波屋義照, Proc. 6 th Jap. Cong. Test. Mat., 61 (1963) ; 大南正菜, 元家勝彦, Proc. 9 th Jap. Cong. Test. Mat, 39 (1966).

11) Davis, E. A., Trans. ASME, Ser. D, 82, 453 (1960).

12) Butcher, B M., and A.L. Ruoff, J. App. Phys., 32, 2036 (1961).

13) Hull, D., and E. Rimmer, Ph1l, Mag., 4, 673 (1959). 